\title{
DISCOS SEDICIOSOS Y VOLANTES PROHIBIDOS. \\ LA MUERTE DE OBREGÓN ENTRE LA CENSURA Y EL INGENIO POPULAR
}

\author{
Jaddiel Díaz Frene* \\ Universidad Nacional Autónoma de México
}

PRELUDIO DE UN ASESINATO

F 117 de julio de 1928, a las 2:20 de la tarde, Álvaro Obregón, entonces recién electo presidente de México, era un hombre con un solo brazo y muchas preocupaciones. Varias ideas recorrían su mente mientras degustaba en el lujoso restaurante La Bombilla una comida preparada en su honor por los diputados de Guanajuato. Una de ellas pudo estar relacionada con el peligro de un asesinato. El 13 de noviembre del pasado año, había sufrido un atentado dinamitero en el bosque de Chapultepec, perpetrado por integrantes de la Liga Nacional de la Defensa de la Libertad Religiosa (fundada el 14 de marzo de 1925), entre los que se encontraban Juan Tirado, Nahum Lamberto y Humberto Pro Juárez. Horas antes, en el Centro Director Obregonista, el periodista cercano, Rafael F. Muñoz, le había advertido sobre el peligro de un homicidio. ${ }^{1}$ También recordaría el Diario de Yucatán, días más tarde, que el

Fecha de recepción: 24 de septiembre de 2016

Fecha de aceptación: 1ํ de febrero de 2017

* UNAM. Programa de becas posdoctorales de la UNAM. Becario del Instituto de Investigaciones Históricas.

${ }^{1}$ Robleto, Obregón, Toral y la Madre Conchita, p. 255. 
general le comentó a su hijo Humberto sobre la responsabilidad de atender a la familia en caso de consumarse su muerte. ${ }^{2}$

La posibilidad de un magnicidio se encontraba relacionada con el malestar de los católicos tras la implementación de rigurosas medidas llevadas a cabo durante el periodo presidencial de Plutarco Elías Calles. ${ }^{3}$ Mientras estos pensamientos podían recorrer su mente, un joven silencioso le dibujaba unos bocetos. Su nombre era José de León Toral y, a diferencia de su modelo pictórico, tenía dos brazos y una sola preocupación: matarlo. En cuestión de segundos, mientras la orquesta típica de Alfonso Esparza Oteo interpretaba "El limoncito", el lápiz fue intercambiado por la pistola y varios disparos segaron la vida del héroe de Celaya. Es aquí donde comienza esta historia.

Imagen 1

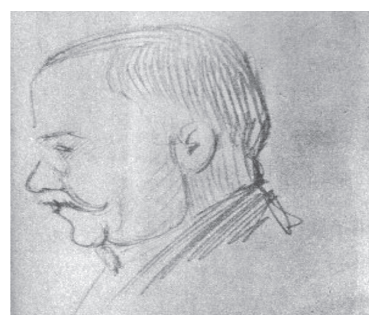

Boceto de Obregón dibujado por José de León Toral.
Imagen 2

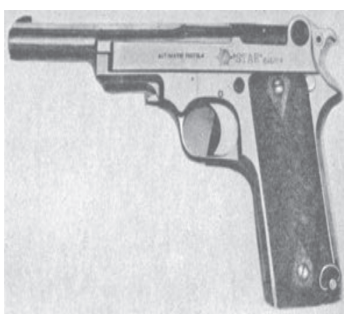

Pistola utilizada por Toral en La Bombilla. ${ }^{4}$

2 Diario de Yucatán (25 jul. 1928), p. 1, cols. 1-2.

${ }^{3}$ Me refiero sobre todo a la Ley Calles promulgada el 2 de julio de 1926 por el presidente Plutarco Elías Calles y puesta en vigor el 31 de julio del mismo año. En el documento, integrado por 33 artículos -más otros tres transitorios-, no sólo se prohibió "el establecimiento de órdenes monásticas", también se determinó que los templos erigidos para servir al culto público "eran propiedad de la Nación representada en el gobierno federal". Los resultados de su implementación alcanzaron saldos significativos, entre los que destacan la clausura de 42 tempos y 76 conventos, así como la expulsión de 185 sacerdotes extranjeros. Finalmente fue abrogada el 14 de agosto de 1931. Véase MALPICA, La influencia del derecho internacional en el derecho mexicano, pp. 100-102. 4 El asesinato de Álvaro Obregón, consultado en http://www.vocesdelperiodista.com.mx, el 22 de mayo de 2013. 
La noticia del magnicidio impactó la vida cotidiana capitalina. El miércoles 18 de julio, Excelsior dio cuenta a sus lectores del desorden citadino ocurrido la tarde del día anterior:

El aspecto de la ciudad, desde que se conoció la tremenda noticia por todas partes con la velocidad de un relámpago, era extraño e inusitado. Posiblemente ningún otro acontecimiento extraordinario de los muchos que ha tocado presenciar a las actuales generaciones, había producido una más honda impresión, ni un mayor sentimiento de estupor y desconcierto como el asesinato de Obregón.

Grupos numerosos de personas se veían obstruyendo las aceras, en el frente de las casas, abordando los tranvías, reflejando en sus semblantes una ansiedad por interrogar a propios y extraños, o bien por cambiar impresiones, referir datos, ratificar informes $[\ldots] .^{5}$

El corresponsal del rotativo no pudo ocultar su sorpresa por el impacto del suceso como un extraordinario catalizador de debates en la vida cotidiana. En sus apreciaciones mostraba varios elementos del funcionamiento de la opinión pública de la época, tales como el interés popular en los sucesos políticos del devenir nacional y el papel desempeñado por los circuitos de transmisión oral, adelantándose a los medios oficiales en la diseminación de la noticia. No tardó mucho para que otros formatos, menos convencionales, circularan en la esfera pública mexicana revelando posiciones políticas diversas sobre el asesinato del "héroe de Celaya".

Lejos de reconstruir los pormenores del magnicidio y sus implicaciones políticas, asunto abordado por la historiografía, ${ }^{6}$ en este artículo intentaremos recorrer un camino metodológico y factual menos transitado, dirigido a captar la construcción de

\footnotetext{
${ }^{5}$ Excelsior (18 jul. 1928), p. 1, col. 3.

${ }^{6}$ Véase, por ejemplo, Loyola, La crisis Obregón-Calles; Meyer, La Cristiada: el conflicto entre la Iglesia y el Estado; CASTRo, Álvaro Obregón; RAmírez RANCAÑo, El asesinato de Álvaro Obregón.
} 
una memoria popular del suceso desde prácticas, narraciones y medios de comunicación poco estudiados, como los discos de fonógrafo y los impresos de cordel. Desde esta mirada, la muerte de Álvaro Obregón y el consiguiente juicio y fusilamiento de José de León Toral, sucesos acaecidos entre el 17 de julio de 1928 y el 9 de febrero de 1929, develan un terreno privilegiado para acceder a una historia popular de la vida política y los usos cotidianos de la comunicación. ${ }^{7}$

Al seguir las causas judiciales, escuchar los discos de RCA Victor y Vocalion o leer las hojas volantes, podemos percibir una situación política extraordinaria que sobrepasó el marco de los debates entre la Iglesia católica y el Estado para mostrarnos el funcionamiento de una opinión pública polifónica. Mediante estos soportes podemos acceder a voces y prácticas de sectores populares como impresores, poetas, cantantes, vendedores, grabadores y otros con mayores recursos, como exitosos impresores y empresarios discográficos. No obstante, debemos resaltar que durante el proceso judicial, los sectores subalternos no se limitaron a la construcción y difusión de opiniones políticas desde los circuitos de comunicación. Campesinos, artesanos y obreros desempeñaron papeles decisivos en la investigación policial sobre la muerte de Obregón y el proceso penal en contra de su presunto asesino. Por ejemplo, Vicente García, Jesús Elorrieta y Jesús Ojeda, todos trabajadores emigrados de España que se desempeñaban como meseros en el restaurante La Bombilla, fueron testigos clave para que las autoridades judiciales

\footnotetext{
${ }^{7}$ Los trabajos de historiadores como Judith Walkowitz sobre los asesinatos de Jack el Destripador en el Londres victoriano, de Elisa Speckman sobre el bandido José de Jesús Negrete en el México porfiriano y de Tomás Cornejo acerca del asesinato de Clara Bell en Chile, han puesto de manifiesto la importancia de estudiar procesos criminales para captar los discursos, las prácticas y los circuitos culturales urbanos de determinado momento histórico. Véase Walkowitz, La cindad de las pasiones terribles; Speckman, Del Tigre de Santa Julia; Cornejo, "Circuitos culturales".
} 
desentrañaran la forma en que murió el connotado caudillo. ${ }^{8}$ Asimismo, el jurado que condenó a José de León Toral estuvo integrado por un chofer de una línea de camiones, un obrero de la fábrica La Alpina, un comerciante de pulques, un mecánico ferrocarrilero, un jornalero que se desempeñaba como peón de caminos y un agricultor de Axotla, entre otros. ${ }^{9}$

Por otro lado, las batallas ideológicas libradas en la vida cotidiana mediante los corridos en impresos y discos fonográficos conducen a explorar la relación entre Estado y cultura popular - una propuesta defendida por historiadores como Daniel Nugent y Gilbert Joseph - desde un prisma privilegiado. ${ }^{10}$ En este sentido, los expedientes judiciales abren las puertas a una historia subterránea de la censura gubernamental y su interés por controlar las narraciones subversivas que, finalmente, sobrevivieron en varias ocasiones gracias a los registros de sus prácticas.

Partiendo de este complejo escenario comunicativo, en las próximas páginas intentaremos responder diversas preguntas. ¿Qué papel desempeñaron las hojas volantes con corridos y los discos de fonógrafo en la difusión y recreación del asesinato de Álvaro Obregón y el juicio y fusilamiento de José de León Toral? ¿Muestran los usos sociales de estos formatos el funcionamiento de una opinión pública homogénea? ¿Es posible captar las voces y las prácticas de los sectores populares tras los procesos de producción, circulación y consumo de estas narraciones poético musicales? ¿En qué medida las autoridades gubernamentales se preocuparon por censurar e impedir la apropiación de estos discursos? ¿Cuáles fueron sus estrategias para imposibilitar la circulación de estos formatos? ¿Adoptaron los comerciantes e impresores una actitud pasiva ante la intervención estatal?

\footnotetext{
${ }^{8}$ Excelsior (11 jul. 1928), p. 12, cols. 4-6.

${ }^{9}$ El Universal (10 feb. 1929), p. 9, col. 3.

10 Véase Joseph y Nugent, "Cultura popular y formación del estado en México".
} 


\section{EL ASESINATO DEL PRESIDENTE ELECTO. DOS CORRIDOS DE SAMUEL MARGARITO LOZANO}

Dos de las obras que se cantaron y leyeron entre 1928 y 1929 con una visión favorable al Estado revolucionario fueron compuestas por Samuel Margarito Lozano. Una de ellas ha llegado hasta nosotros impresa en un volante bajo el título "La muerte del Gral. Obregón”, mientras la otra ha podido sobrevivir en el testimonio de Hernán Robleto, quien presenció cómo el autor cantaba y vendía en hojas sueltas los versos sobre el magnicidio, cinco meses después de la muerte del presidente electo.

¿Quién era este corridista? Samuel Lozano nació en Cuernavaca el 10 de junio de 1891. Fue apresado por las fuerzas villistas y se acogió al perdón para transformarse más tarde en “dorado”. Con el paso de la guerra se convirtió en el trovador más reconocido de la División del Norte, componiendo títulos como "La rielera", "La muerte de Benjamín Argumedo", "La muerte de Zapata" y "Crímenes de Huerta". ${ }^{11}$ Estos datos nos permiten inferir que en 1929 este trovador tenía un alto reconocimiento popular de la audiencia aficionada al género.

El escritor nicaragüense Hernán Robleto, quien presenció el espectáculo popular, describió al vate de la siguiente forma:

Es chaparrito, enteco, decidor, airoso con la guitarra, como una mujer. Cuelgan del clavijero las imprescindibles cintas con los colores verde, blanco y rojo: la amada bandera. Dentro de la caja sonora, por entre el aro de la boca que envuelven como un arco iris las líneas de nácar y cuerno, reluce en el fondo la tricromía de la Virgen de Guadalupe. Y Lozano canta “El Corrido de Álvaro Obregón”: "Fecha diecisiete de julio/fecha tremenda que humilla, /en que a Obregón lo mataron / almorzando en La Bombilla”. ${ }^{12}$

11 “Samuel Margarito Lozano, a 34 años de su fallecimiento" consultado en http://elcuerpoaguanteradio.blogspot.mx, el 2 de mayo de 2013.

12 Robleto, Obregón, Toral y la madre Conchita, p. 274. 
De acuerdo con Robleto, la interpretación de Samuel Lozano se llevó a cabo durante los festejos del aniversario de la Virgen de Guadalupe ante "una heterogénea muchedumbre, en la que prevalece el elemento indígena”. La recordación del caudillo no se reafirmaba sólo en la música, existió también "un retablo con inscripciones", que hacía alusión a la "hazaña" de Celaya, ubicado en una basílica de piedra. Durante la actuación, el público le daba la espalda momentáneamente a la información gráfica, mientras escuchaba el canto de Lozano. Así, la decoración espacial y el corrido se conjugaban en un diálogo simbólico si tenemos en cuenta que en la estrofa número 30 se hacía alusión a la batalla: "En la sierra y la montaña /en Celaya y Ocatlán, /en su grandiosa campaña /siempre lució cual titán". ${ }^{13}$

\section{Imagen 3}

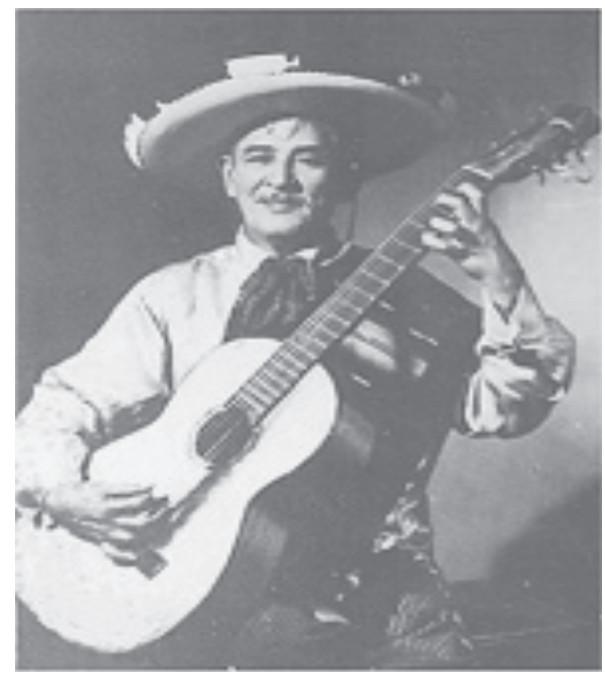

Samuel Margarito Lozano. ${ }^{14}$

${ }^{13}$ Robleto, Obregón, Toral y la madre Conchita, pp. 270-281.

${ }^{14}$ Imagen tomada del sitio http://www.sacm.org.mx. Consultado el 8 de septiembre de 2016. 
Ahora bien, ¿por qué afirmar que los corridos de Lozano defienden una postura "revolucionaria" acerca de la muerte de Álvaro Obregón? En primer lugar, debe señalarse que las obras narraron el suceso de manera detallada, sin falsear, al menos de forma alarmante, la información divulgada por la prensa periódica. Tal procedimiento hubiera sido detectado por una audiencia que constantemente recibía nuevos detalles sobre el magnicidio mediante fuentes oficiales y populares y, al mismo tiempo, pudiera haberle restado prestigio al trovador como cronista noticioso. Por lo tanto, debemos buscar la posición de los poetas en los silencios de la trama, las escenas enfatizadas, la adjetivación de los actores sociales y el diálogo con acontecimientos pretéritos.

Corrido núm. 1 versión cantada

Recordada por Hernán Robleto (fragmento)

1. Era el Presidente Electo $y$ en un banquete se hallaba; ¿quién se iba a imaginar que la muerte lo acechaba?

2. Todo era gozo y contento y alboroto y alegría, en tanto que el asesino pensaba su felonía.

3. En medio del regocijo se le aproxima a Obregón y sacando su pistola le hizo fuego a traición.

4. Hacia la izquierda se inclina ya casi muerto Obregón, mientras humea la pistola del asesino felón.
6. En su vida y en su hogar fué muy bueno y cariñoso, en su vida militar siempre fue un héroe glorioso.

7. Siendo nuestro presidente porque el pueblo en él confió, un asesino inclemente la vida le arrebató. ${ }^{15}$

Corrido núm. 2 versión encontrada en formato de hoja suelta impresa (fragmento)

8. Muerto Francisco Serrano, con Gómez trágicamente, el candidato Obregón fue elegido presidente.

9. Breve, con la mano izquierda, el dibujo le mostró y con la otra, por la espalda, seis tiros le descargó.

${ }^{15}$ Robleto, Obregón, Toral y la madre Conchita, pp. 275-281. 
5. El cielo lo arrebató para vestirnos crespones: ¡cuántos siglos faltarán para ver más Obregones!
10. Así terminó su vida el héroe Manco de León, por sostener sus ideales en aras de la Nación. ${ }^{16}$

Nótese en primer lugar los calificativos que recibieron los protagonistas del suceso. Mientras el occiso fue referido como "presidente electo", "héroe glorioso" y "héroe manco de León”, el homicida se definió como "asesino felón” que le "hizo fuego a traición”. La constitucionalidad de la víctima como mandatario legal y la violación de un código de virilidad debido a la ausencia de enfrentamiento tenían el propósito de devaluar la figura de León Toral.

¿Es posible hacer paralelos entre la narración del corrido y la prensa de la época? Por ejemplo, Excelsior publicó los siguientes editoriales en su edición del 18 de julio de 1928: “Cómo se cometió el asesinato del presidente electo”, “Cómo se acercó el vil asesino", "Testigos oculares refieren cómo fue cometido el vil asesinato". ${ }^{17}$ Ese mismo día, el Diario de Yucatán expuso en sus páginas un mensaje del general Plutarco Elías Calles en el que informaba al gobernador sobre cómo había ocurrido la muerte de Obregón. La manera de referir el magnicidio no difiere mucho de los recursos narrativos de Samuel Margarito Lozano.

GOBERNADOR ESTADO.- MUY URGENTE.-MÉRIDA-CON PROFUNDA PENA PARTICIPO A USTED QUE HOY A LAS CATORCE HORAS Y TREINTA MINUTOS EN UN BANQUETE QUE SE DABA EN LA QUINTA “LA BOMBILLA”, UNIBICADA EN LAS INMEDIACIONES DE ESTA CAPITAL FUE ASESINADO VILLANAMENTE EL PRESIDENTE ELECTO DE LA REPUBLICA GENERAL ALVARO OBREGON PUNTO UN DESCONICIDO FUE APREHENDIDO INMEDIATAMENTE Y POR LO TANTO YA ESTA EN PODER DE LAS AUTORIDADES PUNTO DISPARO POR LA ESPALDA AL EXTINTO PUNTO POR DEMAS ME PARECE HACER A USTED PRESENTE LO QUE SIGNIFICA

${ }^{16}$ Avitia, Cancionero bistórico chilango, pp. 28-32.

17 Excelsior(18 jul. 1928), p. 9. 
ESTA IRREPARABLE PERDIDA Y LO QUE SUFRIRA LA NACION EN ESTOS MOMENTOS CON LA DESAPARICION DEL MAS ALTO DE SUS REPRESENTATIVOS PUNTO PRESIDENTE REPUBLICA, P. ELIAS CALLES. ${ }^{18}$

No sólo las palabras publicadas por el rotativo yucateco creaban un diálogo insoslayable entre el discurso oficial y los corridos de Lozano; también las imágenes referían estrategias cruzadas. En la página del periódico donde se mostró el mensaje de Plutarco Elías Calles, se había incluido la misma fotografía de Obregón que acompañó la hoja volante con el corrido de Samuel Lozano. La misma operación sobre el recurso fotográfico se puede mostrar en otros casos. Por ejemplo, Excelsior publicó al siguiente día de la muerte del general una foto donde aparece "el señor Obregón tal y como llegó a la capital de la República el 15 de agosto de 1914, al triunfo de la Revolución". ${ }^{19}$ Esta imagen había circulado meses antes en un pliego impreso donde el corridista Felipe Flores narraba detenidamente los hechos acaecidos en torno al atentado perpetrado el 13 de diciembre de 1927 contra el caudillo.

Otro elemento expuesto en las composiciones musicales de Lozano es la delimitación del deceso del líder irrepetible como acto sufrido en aras de la nación (estrofas 5 y 10). En la narrativa romántica, la muerte es considerada como el camino al panteón nacional de héroes. Haciendo uso de esos recursos simbólicos un rotativo de la época exaltó la imposible renovación histórica del "héroe de Celaya" de la siguiente manera:

Decíamos en nuestro editorial de ayer, consignando un hecho irrefutable, que el general Obregón era en México el hombre más capacitado para mantener el orden. Ahora el general Obregón no existe, y la verdad es que, después del general Calles, no sabemos quién podrá hacerse cargo de la situación del país. ¿Dónde está el

${ }_{18}$ Diario de Yucatán (18 jul. 1928), p. 1, col. 2.

${ }^{19}$ Excelsior (18 jul. 1928), p. 9. 
caudillo popular en el Ejército, dominador de las masas, experimentado, sagaz, con prestigio en toda la República, que sustituya al general Obregón ${ }^{20}$

El mensaje de Calles era más radical al catalogar a Obregón como el "más alto de los representativos" de la patria. Con la afirmación sobre el occiso, no sólo se intentaba eliminar las sospechas de un complot, sino que también se legitimaba a una estirpe de líderes a la que él pertenecía: aquellos que nacieron con la Revolución y habían generalmente muerto en ella.

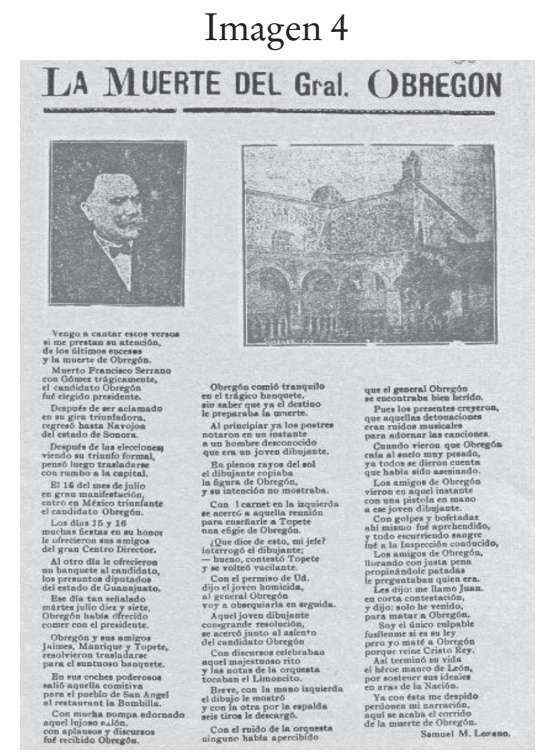

Hoja suelta con un corrido de Samuel Margarito Lozano sobre la muerte de Obregón. Posiblemente se imprimió en la imprenta capitalina Guerrero, ubicada en la calle Correo Mayor. ${ }^{21}$

${ }^{20}$ Excelsior (18 jul. 1928), p. 1.

${ }^{21}$ Avitia, Cancionero histórico chilango, p. 33. 
Por otra parte, vale destacar las alusiones a Obregón como padre de familia en uno de los corridos populares de Lozano: "en su vida y en su hogar/ fue muy bueno y cariñoso". Éste también fue un tema recurrente en los medios oficiales. Mientras el Nogales Herald informaba sobre un infarto sufrido por doña María Tapia al saber la noticia de la muerte de su esposo, el Diario de Yucatán reproducía una conversación, anteriormente referida, entre el general y su hijo Humberto donde le aconsejaba que, en caso de su muerte, él debería encargarse de “la protección y sostén de la familia”. ${ }^{22} \mathrm{El}$ mismo artículo ilustraba la reacción de Humberto Obregón ante el cadáver de su padre en la residencia de Jalisco núm. 185: "Humberto se lanzó a abrazar a su padre, que estaba ensangrentado" ${ }^{23}$ El impacto de la noticia en la esposa y el hijo de Obregón le daba a la prensa y los corridos populares escenas melodramáticas para conmover a las audiencias, pero al mismo tiempo ayudaba a construir el estereotipo de una masculinidad hegemónica nacional en una sociedad que, basada en patrones católicos, necesitaba de los ingredientes del buen padre y el querido esposo. ${ }^{24}$

Por último, debemos destacar el silencio corridista en torno a los actos funerarios del héroe de Celaya. En los versos de Lozano se relatan incluso los preparativos y el traslado de la comitiva hacia el restaurante La Bombilla, pero en sus dos obras la narración concluye en la escena del crimen, a pesar de la amplia información publicada en la prensa periódica sobre el traslado y el entierro de los restos mortales del general, documentados por los rotativos mediante descripciones verbales y fotográficas. ${ }^{25}$

${ }^{22}$ Nogales Herald (1º jul. 1928); Diario de Yucatán (25 jul. 1928), p. 1.

${ }^{23}$ Diario de Yucatán (25 jul. 1928), p. 1.

${ }^{24}$ El concepto de masculinidad hegemónica ha sido definido por Raewyn Connell. Véase Connell, Masculinidades, p. 117.

${ }^{25}$ Por ejemplo, El Informador publicó descripciones sobre el sepelio de Álvaro Obregón. Véase El Informador (18 jul. 1928). 
Podemos inferir, por tanto, la existencia de una relación entre la agenda temática de las composiciones y los posicionamientos políticos que se defendían en la narración de los sucesos. En este sentido, los corridistas que mostraron simpatía por José de León Toral priorizaron hechos como el juicio y el fusilamiento, que permitían victimizar al homicida y sensibilizar a las audiencias, un asunto que podremos ilustrar en las próximas páginas.

DE LA MANSIÓN DEL INFIERNO A LA NACIÓN MEXICANA:

UN RADIOGRAMA DISIDENTE

En los mismos meses en que el público obregonista conmemoraba la muerte del caudillo con las composiciones de Lozano, los grupos defensores de la Iglesia católica disfrutaron un corrido que subvertía estas reivindicaciones: su título era "El radiograma”. La obra, de profusa circulación popular, relataba la llegada de Álvaro Obregón al infierno, así como el encuentro con algunas de sus víctimas políticas entre los que destacaban Venustiano Carranza, Pancho Villa, Carlos A. Vidal, Francisco R. Serrano y Arnulfo R. Gómez. Paralelamente, en el texto eran condenados al mismo destino algunos de los colaboradores más cercanos del general: Luis Napoleón Morones, Antonio Díaz Soto y Gama y Aurelio Manrique. El castigo del caudillo no sólo se reducía a residir en el infierno, sino que también debía ser juzgado por sus víctimas.

Lejos de mostrar la historia de la Revolución como una sucesión romántica de líderes, que más allá de sus diferencias lucharon por el objetivo común de la nación, el corrido popular develaba el proceso como una disputa signada por la traición y el deshonor. Paralelamente, la denostación de Obregón traía consigo la exaltación de León Toral como una especie de vengador temido, aunque su comparación con el general Rodolfo Herrero lo continuaba definiendo como un hombre que había matado a traición: 
En tono afligido y triste

Nos llegó este radiograma

De la mansión del infierno

A la Nación Mexicana

Hoy 17 de julio

Llegó aquí en un gran adiós

Como a las tres de la tarde

El general Obregón.

Pronto lo reconocieron

Gómez, Vidal y Serrano

Pues enseguida notaron

Que le faltaba una mano

En el infierno Obregón

Hizo estas declaraciones

Tras de mí viene en camión

El compañero Morones.

Con apoyo de Lucer

Quiso recobrar la fama,

Pero le faltó Topete,

Su Manrique y Soto y Gama.
Al contar con Satanás

Obregón ya vio confianza

Cuando se la pareció

Don Venustiano Carranza.

Asustado el pobre manco

Su faz se puso amarilla

Cuando salió Lucio Blanco,

Alcocer y Pancho Villa.

Luego habló don Venustiano

Como jefe que había sido:

Vengan Gómez y Serrano

A juzgar a este individuo

Obregón acongojado

Contestó a nada me opongo

No esté usted enojado

Por lo de Tlaxcalantongo

Pero quiere ser sincero

Que me tachen de inmoral

Que si usted tuvo un Herrero

Yo me encontré un León Toral. ${ }^{26}$

Debe destacar que el título del corrido no resultaba extraño para el público de la época. Todo lo contrario, guardaba una relación directa con la labor del recién estrenado medio de comunicación en la propagación de las noticias. Gran número de periódicos, sobre todo aquellos de los estados, señalaban haber recibido las informaciones del deceso del líder por medio de radiogramas enviados desde la capital.

En un estudio reciente, la historiadora mexicana Rosalía Velásquez señaló el papel desempeñado por la radiodifusora CZE en la transmisión de los detalles de la muerte de Obregón.

${ }^{26}$ Transcripción del disco fonográfico El Radiograma, grabado por la empresa Brunswick en El Paso, Texas, el 10 de septiembre de 1931. Cantan G. Guzmán y J. Rosales. Véase SpotTswood, Ethnic Music on Records, pp. 1951-1952. 
En la tarde del 17 de julio de 1928, más de 12 horas antes de que lo hicieran los periódicos, la señal de la CZE fue interrumpida por primera vez para dar a conocer el asesinato del general. La potencia de la estación, con más de 350 metros de onda y recepción en estados como "Puebla, Tlaxcala, Hidalgo, Morelos y cientos de escuelas dotadas con aparatos" garantizaron la efectividad del mensaje transmitido. ${ }^{27}$

En los múltiples espacios públicos de la época, la temeridad hacia León Toral no sólo fue aludida respecto a las élites obregonistas, como se hacía en "El radiograma", sino también en relación con los indomables soldados villistas, de marcado origen popular. Pocos días después del asesinato del presidente electo fue presentada en los teatros capitalinos una obra titulada La Concha Madre, libreto escrito por Gustavo Carlos Villanave. De acuerdo con Armando de Maria y Campos, espectador de la época y amigo del libretista veracruzano, una ovacionada escena transcurría de la siguiente forma:

La escena representaba una taberna en la que se encontraban muchos matones que habían sido "dorados" de Pancho Villa, asaltantes de trenes, todos presumiendo de muy valientes y atravesados. El pobre cantinero intervenía cada rato para ponerlos en paz hasta que uno de ellos tomaba a una de las mujeres que en la taberna se encontraban, y decía: "El que se sienta valiente, que toque a esta mujer”. Nadie se acercaba al fanfarrón, que, además, esgrimía una pistola. En esos momentos entraba un pobre viejo mandadero, con su canasta, e iba a platicar con esa señora, tomándola del brazo. El matachín gritaba: "¡Dije que el que se acerque a esta mujer se moría!”, y dirigiéndose al pobre viejo: “¡Rece su última oración! ¿Cómo se llama usted?” “José Toral”, contestaba serenamente aquel infeliz. El fanfarrón, todos los valientes "dorados", y la parroquia en general que llenaba la taberna, salían corriendo, dejando la escena vacía y provocando las carcajadas del público. El mandadero sacaba

VELÁsquez, “La radiodifusión mexicana: un encuentro con su pasado”, p. 296. 
de su canasta dos huevos de gallina, los colocaba en el mostrador y se preguntaba con sencillez: “¿Por qué se habrán espantado?...”. El telón caía en medio de una ovación clamorosa. ${ }^{28}$

La reconstrucción de la escena ateniéndose al libreto y las reacciones del público pueden impulsarnos a considerar que estos discursos que ridiculizaban al Estado revolucionario fueron bien recibidos por las audiencias teatrales capitalinas, integradas generalmente por sectores populares y de clase media. Al mismo tiempo, estas imágenes políticas sobrepasaron, por medio de los corridos, los territorios bajo la égida de la censura estatal. El propio Armando de Maria y Campos recuerda que "El radiograma" circuló de forma profusa en la zona de mayor insurgencia cristera:

En el centro del país se cantó mucho un corrido en el que el trovador simula haber recibido un radiograma del infierno con motivo de la muerte del general Obregón y su llegada a aquel simbólico lugar en el que es natural que se encuentra $-\sum y$ en que otro se los podía encontrar? - a sus compañeros de armas de la Revolución Mexicana. El corridista lo hace dialogar con todos ellos y pone en boca de unos y de otros frases que de haber sido posible este diálogo, tal vez habrían pronunciado dichos personajes. ${ }^{29}$

Resulta fácil imaginar un campamento cristero con soldados y oficiales cantando con alegría en la oscuridad o a la luz de las hogueras el famoso corrido. Pero, ¿fue la oralidad el único soporte que intervino en la circulación de este texto disidente?

Tres años después del deceso de Obregón, la empresa fonográfica Brunswick grabó el mencionado corrido en las voces de

\footnotetext{
${ }^{28}$ MARIA y CAMPOS, El teatro de género chico en la revolución mexicana, pp. 317-318.

${ }^{29}$ Maria y CAmpos, La revolución mexicana a través de los corridos populares, p. 36.
} 
Guadalupe Guzmán y J. Rosales, en un estudio ubicado en El Paso, Texas. El disco producido por la empresa estadounidense constituía una mediación tecnológica y extranjera de la cultura oral mexicana, pero también una estrategia de supervivencia de los corridistas norteños, empresarios y tenderos de gran parte del territorio nacional que se beneficiaban del negocio musical. ${ }^{30}$

\section{Imagen 5}

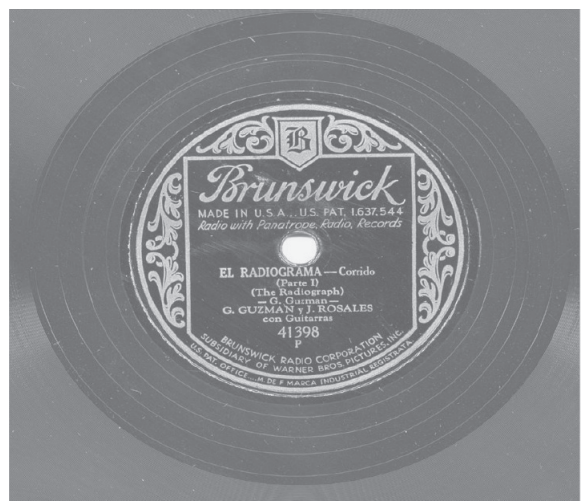

Disco de fonógrafo con el corrido "El radiograma", grabado por la empresa Brunswick. ${ }^{31}$

Esta práctica no era nueva. A lo largo de la Revolución, empresas como Columbia y Victor (convertida luego en RCA Victor), entre otras, grabaron corridos en que se ilustraban las hazañas y desgracias de los caudillos más connotados del proceso, como Emiliano Zapata, Pancho Villa, Francisco I. Madero y el propio Obregón. Estos discos, de 78 revoluciones por minuto, estaban dirigido fundamentalmente a un mercado de habla hispana radicado en el territorio mexicano y en el sur de Estados Unidos.

30 SpotTswood, Ethnic Music on Records, p. 1951.

31 The Strachwitz Frontera Collection of Mexican and Mexican American Recordings, UCLA, consultada en http://frontera.library.ucla.edu/, el 22 de abril de 2013. 
El antropólogo Manuel Gamio señaló en su trabajo Mexican Immigration to the United States, publicado en 1930, la presencia de los fonógrafos en la vida cotidiana de los inmigrantes mexicanos radicados en el vecino del norte, así como la profusa circulación de los artefactos hacia México, traídos por aquellos que retornaban a "casa". De acuerdo con los registros aduanales de 1927, fecha cercana a la muerte de Obregón, pasaron la frontera hacia el territorio nacional 2104 personas portando 270 fonógrafos y 2706 vinilos. Ahora bien, debe tenerse en cuenta que, aunque la cifra de discos supera el número de retornados, en realidad se trata de las obras no censuradas por el gobierno. Grabaciones que atentaban contra el gobierno, como es el caso de "El radiograma", debieron burlar la vigilancia de las aduanas. ${ }^{32}$

En una descripción estandarizada de la vivienda de inmigrantes provenientes de una vecindad de la ciudad de México - y especialmente residentes en San Antonio, Texas-, Gamio incluye la presencia de un fonógrafo:

This is a sort of tenement, or many one- or two-room dwellings around a court with common water supply and toilets. It is a type to be found especially in San Antonio. Sanitary conditions are generally bad, though sometimes individual dwellings are clean and fairly decently furnished. The furniture is of cheap American can manufacture, bought on the instalment plan, and very frequently even in a poor house there is a phonograph or even a piano. ${ }^{33}$

Los salarios percibidos por los trabajadores mexicanos en Estados Unidos les permitían invertir en productos de una nueva era de modernidad y confort, como automóviles, refrigeradores y fonógrafos. ¿Pero sólo los trabajadores mexicanos emigrantes podían acceder a las codiciadas máquinas de sonido? ¿Hasta qué punto los sectores populares residentes en territorio

32 Gamio, Mexican Immigration to the United States, p. 226.

${ }_{33}$ Gamio, Mexican Immigration to the United States, pp. 146-147. 
mexicano contaron con una infraestructura fonográfica que les permitió acceder a los corridos de Obregón?

Varias estrategias comerciales posibilitaron que estos grupos con bajo nivel adquisitivo pudieran convertirse en receptores de los discos fonográficos. Una de ellas fue el alquiler de los artefactos a compañías estadounidenses, quienes encontraron un buen mercado en aquellos clientes imposibilitados de pagar completamente un artefacto. Sabemos, por ejemplo, que la compañía Industrias Unidas, con sede en Balderas, se dedicó a la renta de vinilos y máquinas parlantes en los años veinte. Algunas demandas judiciales de la empresa contra ciudadanos residentes en la capital, como Rosa A. de Acevedo, Pablo Flores, José Prevé y Zenaido Hernández, entre otros, dan cuenta de determinadas estrategias de resistencia para burlar los altos desembolsos exigidos por la empresa. ${ }^{34}$

Otras posibilidades adquisitivas dependieron de la suerte y las rifas de los grandes consorcios. Siete días antes del fusilamiento de León Toral, Excelsior publicaba un anuncio publicitario que llenaba de esperanza a los sectores populares. Un avión sobrevolaría la capital arrojando cientos de cupones que darían acceso a determinados productos, entre ellos, "magníficos fonógrafos". ${ }^{35}$

Pero fuera del espacio capitalino, los sectores marginales también aprovecharon las diferentes ofertas que propiciaba el mercado mexicano. En las observaciones del antropólogo y etnógrafo Alfonso Villa Rojas encontramos una ventana privilegiada para apreciar cómo los fonógrafos arribaron al campesinado indígena residente en Yucatán que laboraba en el cultivo del chicle:

En 1936 y 1937 el chicle fue vendido a 44 pesos quintal (5 marquetas), precio que a los nativos parecía demasiado bajo en comparación

34 AGN, Tribunal Superior de Justicia del Distrito Federal, c. 1864, fols. 336779,336778 y 336731 ; c. 1890 , fols. 342239,342241 y 342240.

35 Excelsior (2 feb. 1929), p. 9. 
con el de años anteriores [...]. No teniendo los indígenas aspiraciones de mejoramiento social, malgastaban el dinero así obtenido (en la explotación del chicle) en grandes borracheras o artículos superfluos, tales como fonógrafos, máquinas de coser o lámparas de mano, todo lo cual quedaba pronto inservible por falta de costumbre y destreza en su manejo. ${ }^{36}$

Al parecer, las apreciaciones de Villa Rojas no revelaron un fenómeno aislado. Una investigación realizada en el mundo rural mexicano a inicios de la década de 1930 mostró que en $53 \%$ de las 703 comunidades indígenas estudiadas se poseía un fonógrafo, un porcentaje superior al de las 956 comunidades blancas y mestizas que formaron parte de la muestra. ${ }^{37}$

Vale destacar que la circulación de "El radiograma” se llevó a cabo, generalmente, mediante los circuitos orales de transmisión, tal como lo recuerda Maria y Campos. Su conversión al vinilo fue ejecutada en un momento en el que la muerte de Obregón no era un suceso de inmediatez noticiosa. Esto explica, en parte, la ausencia de documentos que refieran la censura estatal de la grabación.

\section{CERRAR LAS ADUANAS, CONTROLAR LOS OÍDOS}

No obstante, las obras musicales producidas en los días del proceso judicial no corrieron la misma suerte. El 7 de diciembre de 1929, la Secretaría de Gobernación transmitió a las aduanas mexicanas, mediante la circular número 14659, la necesidad de impedir que un disco de fonógrafo llegara a territorio nacional. ¿Por qué un simple vinilo de 78 revoluciones por minuto causaría tanto revuelo burocrático?

\footnotetext{
${ }^{36}$ VIlla Rojas, “Los mayas del actual territorio de Quintana Roo”, p. 162.

37 Tannembaum, "Technology and Race in Mexico", p. 383. Para una versión más amplia de los procesos de recepción y circulación de los discos de fonógrafo véase Díaz Frene, “A las palabras ya no se las lleva el viento”.
} 
La actitud del gobierno mexicano comienza a tener sentido si señalamos el título de la pieza grabada: "El corrido de León Toral". Al parecer, el flujo de las grabaciones musicales sobre el asesino de Obregón había comenzado rápidamente a traspasar la frontera norte y los partes de las diferentes aduanas dan cuenta del temor de las autoridades. En una carta fechada el 16 de agosto de 1929 y dirigida al secretario de Gobernación, el administrador de la oficina de correos de Santa Rosalía reconocía haber extraído de los bultos postales manejados por la oficina regional 15 discos con la música subversiva. ${ }^{38} \mathrm{Al}$ mismo tiempo, la aduana de Tampico le decomisó al señor Diego Alonso Hinojosa ocho cajas con la composición censurada. A pesar de que el propietario de la mercancía solicitó la reexportación de los vinilos el 13 de enero de 1930, la Secretaría de Gobernación respondió con una negativa rotunda ${ }^{39}$ Por su parte, el 6 de julio de 1929, el director de la Aduana de La Paz informó sobre la confiscación de 50 discos "marca Vocalion Records" con el corrido a León Toral que le habían sido incautados al señor Ricardo García. ${ }^{40}$

Los partes aduanales señalan que los más perjudicados con las confiscaciones fueron pequeños agentes dedicados al comercio de grabaciones fonográficas. Entre los que sufrieron más pérdidas se encontraba el señor Agustín R. Luna, quien fue víctima de varias incautaciones a mano de aduaneros tampiqueños. Agustín R. Luna y su hermano eran agentes para la zona de Tampico y Villa Cecilia de la marca de fonógrafos Polyphon. Tal como se acostumbraba, también se dedicaron a la venta de discos que compraban a diferentes empresas estadounidenses, entre las que encontraba la Okeh Phonograph. Precisamente esta

${ }^{38}$ AGN, Secretaría de Gobernación, Siglo XX, Investigaciones Políticas y Sociales, c. 0016, exp. 040-1, p. 5.

39 AGN, Secretaría de Gobernación, Siglo XX, Investigaciones Políticas y Sociales, c. 0016, exp. 040-1, p. 20.

${ }^{40}$ AGN, Secretaría de Gobernación, Siglo XX, Investigaciones Políticas y Sociales, c. 0016, exp. 040-1, p. 1. 
compañía norteña les había enviado 300 piezas con el "Corrido de León Toral” el 19 de septiembre de 1929 en el vapor Pánuco, las cuales fueron decomisadas.

Sin embargo, para beneplácito de esta investigación, la actitud de los afectados no fue sumisa. Sus intentos de rescatar la mercancía "sediciosa" nos aportan una invaluable información para desentrañar el funcionamiento de los circuitos comerciales de la época.

En una misiva dirigida al propio secretario de Gobernación los comerciantes mexicanos denunciaron la desigualdad en la aplicación de la censura. En primer lugar, criticaron el trato del administrador de la aduana, quien no les había devuelto el cargamento y sólo se había basado en el título de las obras para ejecutar su detención. En este sentido, les informaban al secretario de Gobernación que tal corrido no era ofensivo al gobierno, ya que su venta se llevaba a cabo libremente por otras casas comerciales dentro del territorio mexicano, destacándose el negocio capitalino de J. Canto:

El corrido impresionado en el disco a que nos referimos no tiene nada absolutamente insultante para el Gobierno, ni nada que pudiera considerarse ofensivo y la mejor demostración de esto, es el hecho de que se encuentra a la venta en todos los establecimientos del ramo en esa capital, lo distribuyen en México la casa del Sr. J. Canto situada en la calle de Corregidora No. 29 A., quien la ha introducido por el puerto de Veracruz sin que nadie lo impidiese. ${ }^{41}$

Si como plantea la carta, la censura de los discos sólo se ejecutó a partir de los títulos, es muy posible que empresas y agentes hayan introducido cargamentos clandestinos cambiando la estafeta de los vinilos. También deben considerarse cuestiones como el soborno a las autoridades y otras tácticas del comercio ilegal.

${ }^{41}$ AGN, Secretaría de Gobernación, Siglo XX, Investigaciones Politicas y Sociales, c. 0016, exp. 040-1, pp. 17-18. 
Pero los inconformes empresarios acudieron a otro recurso para probar la injusticia a la que habían sido sometidos. Adjuntaron la carta de un cliente de San Luis Potosí donde se expresaba que el disco sobre Toral se vendía "libremente" en este "estado" dirigido por un gobierno calificado entre los más "revolucionarios" y de "ideas más avanzadas". Éste, continuaba la carta, "no permitiría la venta de este disco si contuviera frases insultantes para el gobierno". ${ }^{42}$

¿Quién era este cliente de "Agustín Luna y Hermano" que aseguraba que en San Luis Potosí se vendía libremente el "Corrido de León Toral”? ¿Qué elementos en su carta resultan reveladores sobre el disco en cuestión?

Se trataba de Antonio Camargo, dueño de una "mercería mexicana" ubicada en la calle 4 de Morelos con el número 23 "junto al correo". Su carta, enviada 27 días después de la entrada del vapor Pánuco a Tampico con la mercancía decomisada a los Luna, señalaba lo siguiente: "Entiendo que solo a ustedes les fue recogido el disco con el Corrido de Toral, primera y segunda parte, porque en ésta lo ha seguido vendiendo bien la VICTOR. Si ya los pueden Us mandar les estimarían me vinieran solamente unos 10 por ahora" $[s i c] .^{43}$

La lista de discos solicitada por Camargo incluía otros títulos: "Tampico hermoso" (8 ejemplares), "Gloria con Luna y plata" (8 ejemplares), "Carreras con niño Fidencio" (4 ejemplares) y "El carbonero" (8 ejemplares), pero indudablemente era la creación musical sobre León Toral la que despertaba más interés. Tal demanda discográfica no era aislada en esa época, incluso en las zonas más pobres. Ante una radio en ciernes, los fonógrafos se convirtieron en el centro de fiestas y tertulias pueblerinas. La escucha comunitaria constituía una estrategia generalizada

${ }_{42}$ AGN, Secretaría de Gobernación, Siglo XX, Investigaciones Politicas y Sociales, c. 0016, exp. 040-1, p. 18.

${ }^{43}$ AGN, Secretaría de Gobernación, Siglo XX, Investigaciones Políticas y Sociales, c. 0016, exp. 040-1, p. 15. 
para los sectores populares, quienes, debido a su analfabetismo, encontraban en las "máquinas de sonido" un medio que, a diferencia de la letra impresa de los pliegos de cordel y los periódicos, no les ofrecía ningún obstáculo cultural como receptores.

Las palabras de Ceferino Juárez, un campesino nacido en 1902 en el municipio Villa de Juárez, resultan relevantes para percibir los usos sociales de los fonógrafos por los sectores iletrados de la región potosina. Sus memorias, recogidas por Eliazer Velásquez, muestran cómo incluso en las zonas más recónditas existió una infraestructura tecnológica para escuchar el corrido de León Toral y otros temas musicales relacionados con la política nacional:

Cuando tenía cinco o seis años ya le había aprendido la sonería a mi padre. Se me había grabado en la mente. En 1913 nos fuimos para Agua de En medio. Se vino la Revolución, y para el 15 ya no pudimos estar. Nos radicamos en Cerritos [...].

También andando con mi papá grabaron unos discos de fonógrafo, eran unos tubitos anchitos y larguitos; los metían en el fonógrafo y chillaban: sss ... se ponía uno las tripitas en los oídos. Eso fue en el año del 17. Ahí quedó la música grabada. Mi hermano la tenía, pero se le descompuso el motorcito. Todo quedó en nada, pero me quedé con la base más o menos de lo que él tocaba [...].44

Queda por indagar hasta qué punto los discos fonográficos con el corrido de Toral eran ofensivos para el gobierno, tal como aseguraba la Secretaría de Gobernación. ¿Habían sido escuchados realmente por los burócratas mexicanos o se trataba sólo de una censura basada en el título? Indiscutiblemente se trata de cuestiones que sólo pueden ser respondidas si seguimos el consejo que los Luna les daban a las autoridades: escuchar su contenido.

${ }_{44}$ Entrevista realizada por Eliazer Velásquez, fragmento tomado de Martínez, 2008, p. 18. 
Este ejercicio nos conduce a un detalle que escapa al diálogo entre los comerciantes y la censura estatal. La circular dirigida a las aduanas ordenaba la detención de los vinilos que portaran "El corrido de León Toral", pero los partes evidencian la captura de composiciones musicales producidas por tres compañías diferentes. Por ejemplo, mientras la aduana de La Paz confiscó 50 unidades de Vocalion Records y el cargamento de los Luna contenía grabaciones de la Okeh, el pedido del cliente de Potosí hacía referencia a las obras vendidas por la RCA Victor. Entonces la pregunta parece inminente: ¿tenían todas las piezas la misma composición musical?

Los discos Vocalion Records y los producidos por la Okeh portaban las estrofas tituladas "El corrido de José Toral, primera y segunda parte”. A pesar de contar con los mismos textos, variaban los intérpretes y la entonación, elementos que mediaban el sentido de la letra. Mientras la Vocalion decidió contratar la voz de los Trovadores Tapatíos, la Okeh contó con los servicios del barítono Fortunio Bonanova. ${ }^{45}$ Por su parte la RCA Victor, aunque mantuvo el título similar al establecido por sus competidoras "El corrido de Toral", llevó al mercado una obra con un texto totalmente diferente, para lo cual contó con la interpretación del dueto Peña y Mena, que en 1929 había grabado títulos como "La geografía”, "El Alacrán”, "Adán y Eva”, "Los picaditos", "Ir por lana", "Las campanas de Belén” y "Día de Muertos", entre otros. El contenido menos ofensivo del corrido grabado por la RCA Victor explica, en parte, la postura

${ }^{45}$ Sin embargo, debe precisarse que la Vocalion Records, al parecer, aprovechando la demanda producida por la guerra cristera grabó otro corrido titulado "El fusilamiento de Toral" en las voces del "Dúo Mexicano". Por su parte, la Brunswick grabó también el "Corrido de Toral” en Chicago el 21 de febrero de 1929. No he podido revisar esta grabación, pero resulta interesante que, de acuerdo con los registros de la empresa, sus intérpretes fueron "Los Bernardini”, auxiliándose de guitarra y mandolina. Véase LAIRD, Brunswick Records, p. 1061. 
pasiva del gobierno "revolucionario" del estado de Potosí ante la circulación de la obra musical. ${ }^{46}$

El hecho de que la censura estatal haya funcionado con base en los títulos y no en los textos ayuda a explicar, en parte, por qué las autoridades aduanales, como pudimos observar, terminaron decomisando todo lo que estuviera relacionado con un corrido acerca de Toral. De cualquier forma, resulta sospechoso que, a pesar del extendido operativo de censura a lo largo de la frontera, sólo se hayan reportado tres decomisos aislados, si se tiene en cuenta el inmenso tráfico disquero.

\section{Imagen 6}

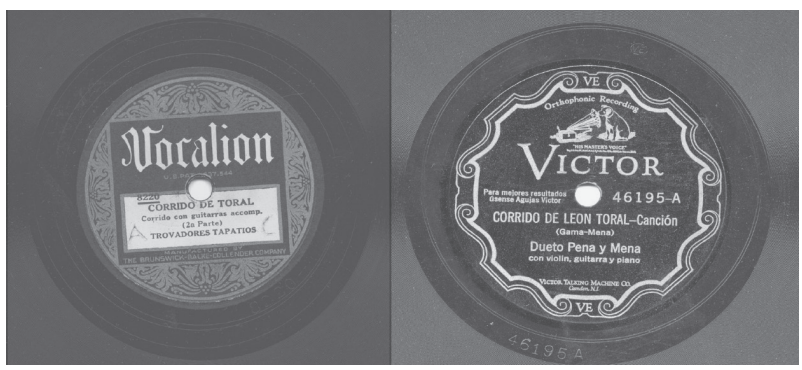

Discos de fonógrafo producidos por las empresas estadounidenses Vocalion y RCA Victor con el "Corrido de León Toral”. ${ }^{77}$

Los secretos textuales del disco subversivo

Finalmente, podemos confirmar que la versión musical de los hechos grabada por las empresas Okeh y Vocalion tenía varios elementos narrativos que nos permiten explicar la actitud del gobierno. En el corrido, José de León Toral era calificado como un "mártir de su religión" y no como un "asesino

\footnotetext{
${ }^{46}$ Véase Laird y Rust, Discography of Okeh Records.

${ }^{47}$ Strachwitz Frontera Collection of Mexican and Mexican American Recordings, UCLA, consultada en el sitio http: //frontera.library.ucla.edu/, el 22 de abril de 2013.
} 
vil", como ocurría en las composiciones "oficialistas" de Samuel Lozano. La construcción de su imagen mesiánica tuvo un ingrediente principal en el sufrimiento indoblegable ante la tortura de la policía. En una estrofa se expresaba: "sus jueces quisieron sacarle la verdad/ y crueles tormentos su cuerpo sufrió/Jamás una queja su pecho exhaló". ${ }^{48}$

Debe señalarse que el propio acusado contribuyó a edificar su imagen como redentor a partir de sus múltiples alegatos ante el tribunal. El periódico El Universal publicó el 4 de noviembre de 1928 las declaraciones de Toral sobre el tormento recibido en la prisión durante los primeros interrogatorios. Ante los medios de comunicación, familiares y jueces, el acusado recordó el diálogo sostenido con uno de sus torturadores de la siguiente forma: "Entonces uno dijo: ¡no podrá resistir! Y yo le contesté: ¡Dios me dará fortaleza!” ${ }^{49}$ Después de la terrible confesión, Toral, en un acto de reminiscencia bíblica, perdonó a sus verdugos. Así lo describía el corresponsal de El Universal: "'Y ahora señores Jurados, voy a hacer un juramento'. Toral extiende la mano y dice: ' $¡ Y$ Yo a todos los que me han martirizado no les guardo el menor odio, hoy les besaría la mano delante de todos"”. ${ }^{50}$

La narración periodística nos anuncia un momento histórico de profunda dramatización de la vida política. En la descripción del juicio, el corresponsal se convertía en un narrador novelístico que describía las actitudes y estados de ánimos de cada personaje, infligiéndole más dramatismo al proceso judicial.

Otra estrategia del corrido sedicioso para consternar a las audiencias se basó en las referencias a los hijos y la esposa del acusado, quienes quedarían abandonados tras su fusilamiento:

\footnotetext{
${ }_{48}$ Transcripción del disco fonográfico Corrido de Toral, grabado por la empresa Vocalion en la voz de Los Trovadores Tapatíos (Chicago, 21 de febrero de 1929). Consultado en http://www.laits.utexas.edu

${ }^{49}$ El Universal (4 nov. 1929), p. 3.

${ }^{50}$ El Universal (4 nov. 1929), p. 3.
} 


\section{Y cuando la esposa y su tierno hijo \\ fueron a la cárcel por última vez, toral ya con calma, sonriendo, les dijo: -Junto a nuestro padre, Junto a nuestro padre, \\ Los veré después.-}

La esposa querida, la mujer amada, con el hijo en brazos, cayó arrodillada, por su amante esposo pedía compasión. ${ }^{51}$

El último encuentro de Toral con su pequeño hijo, referido en la pieza musical, fue motivo de múltiples alusiones por la prensa. Uno de los periodistas que obtuvo permiso para entrar a la prisión escribió haber oído de "labios de Toral” que su "momento más angustioso había sido el que pasó la noche anterior, cuando le fue llevado su hijito Humberto, recién nacido". De acuerdo con el testigo, las últimas palabras del prisionero, antes de ser llevado por el coronel Islas hacia el paredón de fusilamiento, fueron “¡Pobre hijo mío!”. ${ }^{52}$ En las confesiones del acusado ante el tribunal, el sacrificio individual de la paternidad se entendía como prueba de su redención por una colectividad cristiana:

Yo iba a dejar viuda a mi esposa y huérfanos a mis pequeños niños; pero era verdad también que dejaría viuda a la esposa del General Obregón y sin protección a los hijos de éste. ¿Pero qué valen estos dolores frente a la inmensa cantidad de viudas y huérfanos de la guerra interminable ?53 $^{53}$

Así, la capacidad de soportar el tormento, el abandono de la familia, la entrega a una causa colectiva y su indoblegable fe

\footnotetext{
${ }^{51}$ Transcripción del disco fonográfico Corrido de Toral, grabado por la empresa Okeh en Nueva York el 22 de mayo de 1929. Canta Fortunio Bonanova. ${ }_{52}$ El Universal (10 feb. 1929), p. 1.

${ }^{53}$ El Universal (10 feb. 1928), p. 1.
} 
convirtieron al joven católico en un mesías de la contemporaneidad mexicana.

Un cronista de la época observó el impacto de su figura en múltiples seguidoras femeninas quienes, detrás del cordón de policía que cuidaba la sala del juicio, esperaban cualquier noticia sobre el detenido:

Los jardinitos son comederos de alegres comadres que darían algo de su propia vida para escuchar el timbre de la voz de León Toral. Éste goza ya un super cartel entre las mujeres que forman esos corrillos en San Ángel. Es un personaje más fuerte que cualquier estrella de la pantalla cinematográfica [...] Muchas llevan retratos del homicida que muestran y pasan de mano en mano. ${ }^{54}$

Ambos deseos de las audiencias fueron complacidos. Por una parte, la voz de León Toral fue llevada a hogares y escuelas que contaban con radio a través de las ondas de la estación CZE. ${ }^{55}$ Por otro lado, la imagen del homicida se incluyó de forma profusa en periódicos y revistas, acompañada de extensas crónicas sobre su vida. Los impresos populares no desaprovecharon la oportunidad para quedar bien con los seguidores católicos sin violar las pautas de la censura estatal. Así, en un pliego anónimo de la época se incluyó un corrido en el que, al mismo tiempo que se resaltó el valor de Toral por no delatar en los interrogatorios a la madre Concepción Acevedo de la Llata, se justificaba el fusilamiento "del matador inhumano" por el "horrendo crimen” de Obregón. Una de las codiciadas fotos del homicida fue incluida en el volante callejero como un eficiente dispositivo de seducción visual. ${ }^{56}$

${ }^{54}$ El Universal (4 nov. 1928), p. 1.

55 Velásquez, “La radiodifusión mexicana”, p. 296.

56 El peligro que las autoridades vieron en las imágenes puede evidenciarse en la prohibición de fotografiar el fusilamiento de Toral. Incluso, cuando un avión intentó sobrevolar la cárcel con un fotógrafo a bordo para captar la escena, una 


\section{Imagen 7}

\section{EL.J URADO DETORAL}

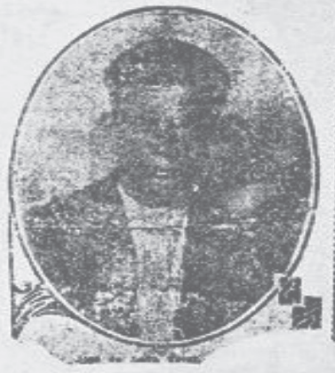

Qve fud sentenciado a la Pena de Muerte

Y la Madre Conchita a 20 allos de prisióo.

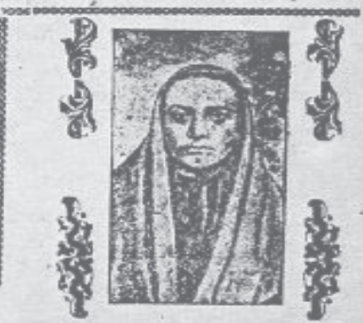

Ia Li: LY tare que fumplire.

"w. Treal for cradento

Jereg ocho de noviement

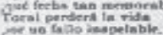

Twmbite is Madre Conchica

can veinte shot de prinic

Ternt, canal un catullero.

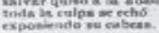

Sanie we lo lirge a creet

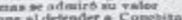

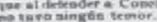

Serscas: que nos coot.

ciot eastign los creve:

no ture de anindo amomo.

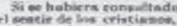

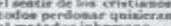

tostoe perbosiar ynicier
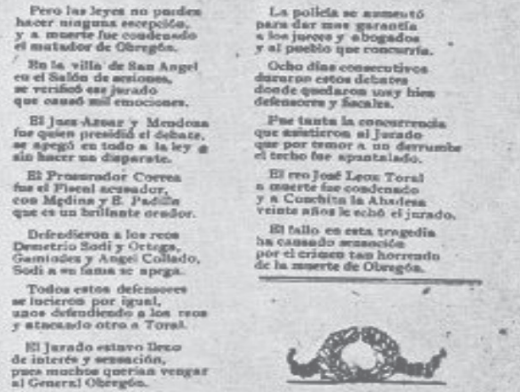

Hoja suelta titulada "El jurado de Toral" ${ }^{57}$

El fervor que manifestaron hacia Toral algunos sectores explica el interés de los empresarios para importar al país las crónicas fonográficas y los esfuerzos de las autoridades por impedirlo. El decomiso de los discos en la zona fronteriza fue, tal vez, la medida menos agresiva que se promovió contra estos discursos que alteraban el orden público y contradecían las versiones oficiales. Por ejemplo, la noche del 4 de julio de 1929, el prolífico

aeronave del ejército lo impidió obligando su descenso.

57 Avitia, Corrido bistórico chilango, p. 38. 
libretista teatral Carlos G. Villanave fue apresado, llevado a la frontera y entregado a las autoridades estadounidenses como un criminal peligroso. De la manera más satírica, el escritor nacido en Orizaba en 1898 y autor de la subversiva obra La Concha Madre fue acusado de ser sirio libanés y expulsado de su país. En el expediente judicial promovido en su contra se alegaba la legalidad de tal procedimiento con base en el artículo 33 de la Constitución mexicana. ${ }^{58}$

UNA HOJA SUBVERSIVA Y UNA IMPRENTA INTERVENIDA. LITERATURA DE CORDEL Y CENSURA EN LA CIUDAD DE MÉXICO

La censura del gobierno mexicano hacia los discursos populares que mostraron simpatía por el asesino de Obregón no sólo se constriñó a la persecución de discos fonográficos, sino que también se extendió a los impresos populares que circulaban en la capital. ¿Es posible encontrar huellas que revelen esta actitud? En febrero de 1929, agentes policiales allanaron la sede de la imprenta de Eduardo Guerrero, ubicada en el número 101 de la calle Correo Mayor. El objetivo de las autoridades consistió en el embargo de hojas volantes que contenían una obra titulada "Fusilamiento de León Toral y su triste despedida", escrita por el poeta popular Jorge Peña. Su precio de 5 centavos era el habitual para este tipo de impresos.

El expediente judicial es particularmente rico en silencios. No existe referencia alguna sobre la lectura que las autoridades hicieron del corrido, señalando qué ideas encontraban transgresoras. Tampoco se precisan detalles sobre la circulación de los impresos o la identidad del poeta, elementos que debieron ocupar un lugar central en el interrogatorio realizado al dueño de la

${ }^{58}$ Maria y Campos, El teatro de género chico en la Revolución Mexicana, p. 318. 
imprenta. Del mismo modo, desconocemos si hubo un delator que informó sobre el peligroso contenido de la obra.

A pesar de estos vacíos informativos, las prácticas de los censores indican la importancia que el gobierno le dio a este tipo de libelo, debido a su impacto en la opinión pública. Además de incautar las hojas volantes con el corrido sedicioso, los agentes clausuraron la imprenta Guerrero, una editorial que había mantenido un protagonismo indiscutible en la década de 1920 en el ámbito de la producción de impresos poéticos sobre la vida política del país.

La medida, que trataba de ser ejemplar para otros impresores dedicados al negocio de la literatura de cordel, no fue acatada de forma pasiva por Eduardo Guerrero. El 19 de febrero de 1929 envió un telegrama al mismo Emilio Portes Gil, presidente de la República, en el que protestaba por la actitud del gobierno, ya que el corrido censurado "careció [de] toda intención dolosa $\mathrm{o}$ ataque [a las] autoridades". Ante esta situación, el impresor concluía suplicando que se le permitiera "volver a trabajar prometiendo ser más cauto en lo sucesivo" ${ }^{59}$ En lo que parece ser un segundo mensaje, Guerrero apeló a estrategias más persuasivas. Por una parte, expresó al presidente que el corrido sobre Toral, además de no contener ofensa alguna, había sido impreso siguiendo la "costumbre". Por otra, exponía su situación económica y su responsabilidad como padre de familia. Ambos elementos pueden apreciarse sin dificultades en el abreviado texto del telegrama:

Secretaría Gobernación clausuróme pequeño taller imprenta por haber impreso en él corridos Fusilamiento Toral. Impreso no contiene ofensa algunas autoridades que debidamente respeto, e imprimiéronse siguiendo costumbre en estos casos. Los trabajos que hago en mi pequeño taller constituyen sostenimiento mi familia. Espero por lo mismo que, siguiendo equidad norma sus actos

${ }^{59}$ AGN, Secretaría de Gobernación, Siglo XX, Investigaciones Politicas y Sociales, c. 33, exp. 31. 
se dignará ordenar retírese clausura devolviéndome taller. A. Reyes Callejón San Juan de Dios, número 22. ${ }^{60}$

Pero, ¿en qué medida el corrido impreso por Eduardo Guerrero podía transgredir la postura del gobierno? ¿Se trataba de una pieza que exaltaba las cualidades de Toral como héroe popular? Si bien carecemos de la lectura que hicieron las autoridades sobre la obra poético musical y por ello no podemos precisar cuáles fueron los fragmentos narrativos que consideraron ofensivos, es posible repasar las visiones expuestas en el texto gracias a que la hoja volante sobrevivió en el expediente judicial.

¿Cuál fue la fórmula narrativa utilizada por Eduardo Guerrero? ¿Hasta qué punto la hoja volante incautada se diferenció de las demás publicaciones?

Un asunto que sorprende a primera vista es el tamaño de la hoja, superior a los demás volantes, lo cual sin embargo no alteró el acostumbrado precio de 5 centavos. Por su parte, las letras sobresalientes del título, declamado como titular noticioso por los vendedores ambulantes, formaban parte de los "dispositivos de composición tipográfica”. ${ }^{61}$

El uso de las imágenes tampoco puede ser pasado por alto. Eduardo Guerrero combinó la fotografía y el dibujo. Mientras un retrato, de forma ovalada, mostraba el rostro de Toral, ya utilizado como reliquia popular por sus múltiples seguidoras, según precisó el cronista de El Universal, el dibujo, con un mayor grado de ficción, intentaba reproducir la escena de su fusilamiento. La exposición de la víctima en el paredón, un escenario abordado en múltiples ocasiones por Eduardo Guerrero y sobre todo por Antonio Vanegas Arroyo desde los días del porfiriato, había demostrado tener la capacidad de seducir la atención de las audiencias.

${ }^{60}$ AGN, Secretaria de Gobernación, Siglo XX, Investigaciones Políticas y Sociales, c. 33, exp. 31.

${ }^{61}$ Martín Barbero, De los medios a las mediaciones, p. 144. 
Ambas imágenes, lejos de ubicarse en la parte posterior del volante, como ocurrió en el caso de las hojas vendidas por Margarito Lozano, se encontraban intercaladas en el relato poético. Desde esta posición, ayudaban a recrear los significados del texto a la vez que imponían divisiones en la narración y, por tanto, cortes en la lectura. Teniendo en cuenta algunos de los elementos señalados, pareciera que el impresor intentaba captar la atención de compradores humildes que, además de estar interesados en leer los versos, valoraran la posibilidad de reutilizar el impreso como objeto decorativo.

Otro de los "dispositivos de seducción"62 del impreso radicaba en la letra del corrido. Jorge Peña, el autor de la obra, logró combinar de forma eficaz la voz del narrador con el relato autobiográfico de José de León Toral. A lo largo del texto se abordaban diversos temas y situaciones. Entre ellos podemos mencionar la negación del amparo, el apoyo recibido por el padre Luis Soto como confesor en la penitenciaría y la relación con la Madre Conchita, cuya influencia en Toral fue destacada por el corridista:

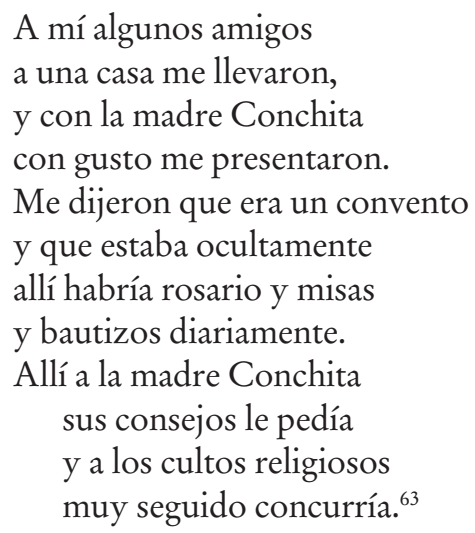

62 Martín Barbero, De los medios a las mediaciones, p. 145.

${ }^{63}$ Peña, El fusilamiento de León Toral y su triste despedida (hoja volante)". 
Imagen 8

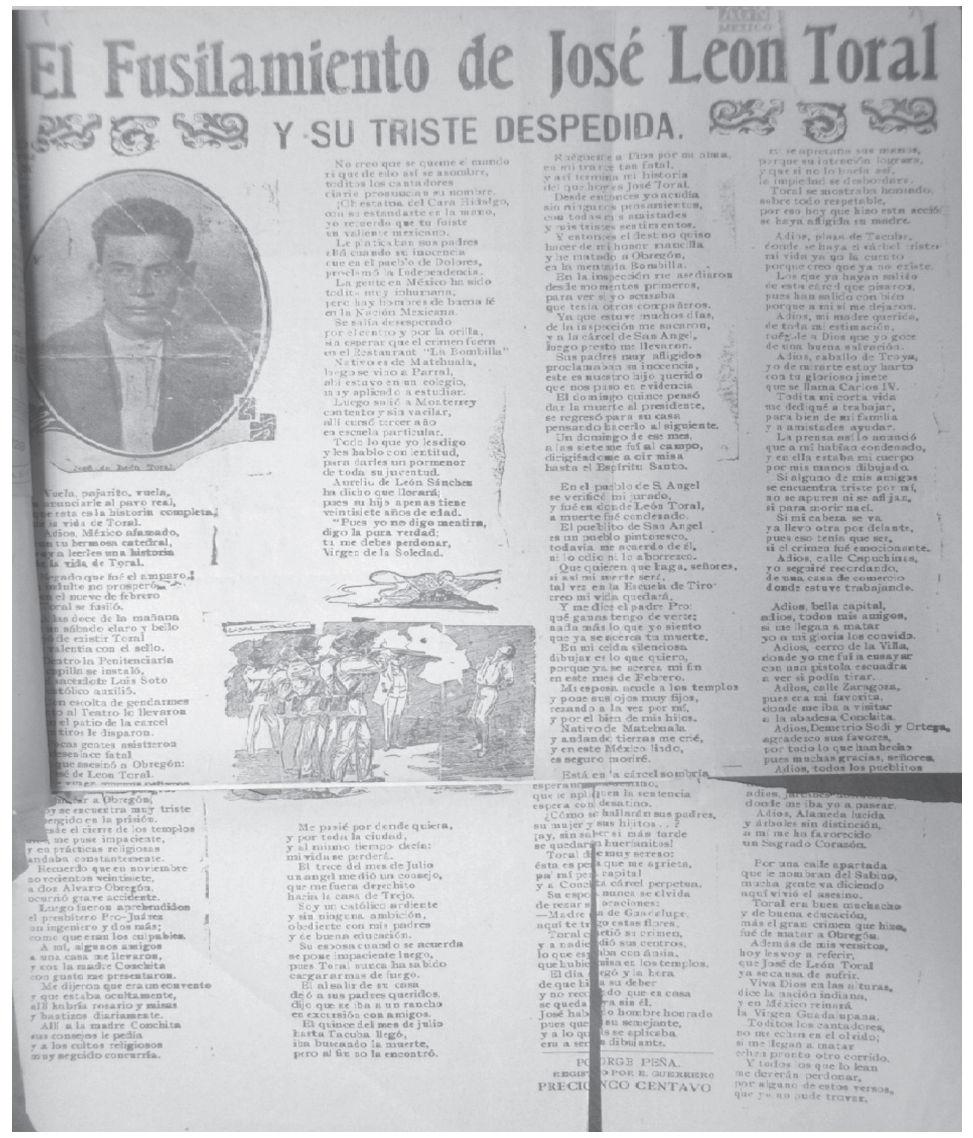

Hoja volante impresa por Eduardo Guerrero, $1929 .{ }^{64}$

Los lamentos de Toral ante la estatua del cura Hidalgo, prócer sobre el que "le platicaban sus padres", intentaban mostrarlo como un hombre con una educación patriótica. ${ }^{65}$ Pudo ser éste

${ }^{64}$ AGN, Secretaría de Gobernación, Siglo XX, Investigaciones Politicas y Sociales, c. 33, exp. 31.

${ }^{65}$ Peña, El fusilamiento de León Toral y su triste despedida (hoja volante)". 
uno de los fragmentos que las autoridades consideraron más ofensivo. Por su parte, otros versos se dirigieron a conmover al público señalando la situación de su familia, una estrategia que se había empleado en otros impresos anónimos y, como ya vimos anteriormente, en los discos subversivos perseguidos por el gobierno. En este sentido, se peguntaba el corridista: “ ¿Cómo se hallarán sus padres,/ su mujer y sus hijitos...?/ay, sin saber si más tarde/ se quedarán huerfanitos" ${ }^{66}$

Como ya era costumbre en otros volantes censurados, el acusado se despedía de su ciudad. En la narración se mencionaban lugares de la capital, como la plaza de Tacuba, la calle Capuchinas, en la cual se encontraba un comercio donde fue empleado, y la calle Zaragoza, que era su "favorita” pues ahí visitaba "a la abadesa Conchita". ${ }^{67}$ Del mismo modo, el corridista mencionaba la calle del Sabino, sobre la cual "mucha gente va diciendo aquí vivió el asesino". Por medio de este recorrido, se recreaban los sentidos de una toponimia capitalina mediada por la vida y la muerte de León Toral.

Tras esta travesía por las experiencias, las enseñanzas familiares, la influencia de la madre Conchita y el móvil del asesinato, Peña concluía que "era un buen muchacho/ y de buena educación,/ mas el gran crimen que hizo/ fue de matar a Obregón”. Al exaltar la figura del homicida de La Bombilla, sin absolverlo por su crimen, el autor parecía intentar complacer tanto a la audiencia cristera como a la obregonista.

Al final de la obra, Toral hacía la siguiente petición:

\author{
Toditos los cantadores \\ no me echen en el olvido; \\ si me llegan a matar \\ echen pronto otro corrido.
}

${ }^{66}$ Peña, El fusilamiento de León Toral y su triste despedida (hoja volante)".

${ }^{67}$ Peña, El fusilamiento de León Toral y su triste despedida (hoja volante)". 
Y todos lo que lo lean me deberán perdonar, por alguno de estos versos, que yo no pude trovar. ${ }^{68}$

¿Qué información nos proporciona este fragmento poético? Por una parte, Peña aprovechaba la voz de Toral para legitimar el impacto de los corridos en la opinión pública de la época y dar cuenta de las preferencias del mediático homicida por el género lírico musical. Por otro lado, el trovador insinuaba que el mismo Toral había escrito parte del corrido. Proponía a los lectores, por tanto, una narración "porosa”"99 que le permitía al público confundir los tiempos, mezclar la ficción con la realidad y alterar las visiones de la política oficial para construir en este mundo que desborda las huellas escritas y se revela en las memorias, otras formas de representar y comprender el pasado.

La atrevida estrategia de escribirle a Emilio Portes Gil dio finalmente resultado. El 25 de febrero de 1929 agentes policiales levantaron los sellos de la imprenta ubicada en el número 101 de la calle Correo Mayor, sin que existieran alteraciones en el local. No obstante, debemos destacar que la censura gubernamental no siempre funcionó con la misma mesura. En 1924, la imprenta Vanegas Arroyo fue destruida por un grupo de hombres enviados supuestamente por Luis Napoleón Morones. Las diferencias en estos procesos de control político y prácticas editoriales subversivas nos comprometen con la necesidad de reconstruir en futuras investigaciones las relaciones entre el Estado y la cultura popular en un periodo de mayor alcance que muestre continuidades y rupturas, así como silencios historiográficos y nuevas posibilidades metodológicas.

${ }_{68}$ Peña, El fusilamiento de León Toral y su triste despedida (hoja volante)".

${ }^{69}$ Martín Barbero, De los medios a las mediaciones, p. 93. 


\section{CONSIDERACIONES FINALES}

El estudio de los corridos sobre la muerte de Álvaro Obregón y el enjuiciamiento de León Toral nos permitió visualizar la cultura popular como un espacio de imaginación y creatividad discursiva, pero al mismo tiempo de constante reelaboración, aceptación o negociación con las elites políticas en un plano local, regional, nacional e incluso familiar.

Para ello, las estrofas poéticas y musicales no fueron pensadas aquí como reductos de la cultura oral e iletrada, sino como efectivos medios de comunicación y, por tanto, fuentes privilegiadas para el análisis histórico. En este sentido, desde nuestra perspectiva y tal como consideramos haberlo demostrado, los corridos logran resolver una de las cuestiones fundamentales de la historiografía en el siglo xx: arribar a las voces de los sectores populares en primera persona.

En este sentido, las composiciones nos permitieron visualizar una opinión pública conflictiva, donde contendían diversas posiciones y criterios políticos. Mientras los corridos impresos y cantados por Samuel Margarito Lozano defendieron la figura del "presidente electo" asesinado a traición por un sujeto sin escrúpulos, los perseguidos vinilos con el "Corrido de Toral" inmortalizaron la figura del homicida como redentor espiritual y padre honorable.

Además de posibilitar la exploración de las narrativas cotidianas, el seguimiento de las obras nos permitió acceder al estudio de dos medios de comunicación poco trabajados por la historiografía mexicana: los pliegos populares y los fonógrafos. Los procesos de producción, circulación y consumo de estos soportes nos ayudaron a esclarecer el funcionamiento de los circuitos comerciales de la época, así como los comportamientos de la censura estatal ante estas manifestaciones cotidianas.

A diferencia de los discos de fonógrafos, los volantes poéticos fueron impresos en el territorio nacional, destacándose en el 
caso de la capital, las imprentas Vanegas Arroyo y Guerrero, la segunda con sede en la calle Correo Mayor, número 101. Indudablemente, esto favoreció la actuación de los censores estatales, quienes podían controlar y sancionar a los sectores sociales inmersos en el proceso de producción de las hojas sueltas.

La forma en que los impresos ayudaron a construir versiones cotidianas sobre la muerte de Obregón y el juicio de Toral no se limitó al uso de los textos. Los impresores también incorporaron a los volantes, las fotografías de los personajes más importantes de la vida política para captar la atención de las audiencias. Sin embargo, las imágenes no sólo funcionaron como dispositivos de seducción; también relacionaron el mundo de las hojas callejeras con la prensa oficial, cuyas páginas surtían a los editores populares de novedosas fotografías que complementaban el mensaje de los textos musicales.

Por su parte, los fonógrafos transformaron la participación de los sectores iletrados en el mercado de las noticias. Décadas antes que la radio, las máquinas parlantes rompieron la hegemonía de la letra impresa, cuyos códigos gráficos habían limitado la recepción del público analfabeto. Los discos, además de hacer posible que las voces de los corridistas más famosos de la época llegaran a los hogares mexicanos, también funcionaron como medios efectivos de difusión de los últimos acontecimientos nacionales.

La grabación de estas piezas por las más connotadas compañías estadounidenses nos condujo a varias consideraciones. En primer lugar, nos dio a conocer la amplia demanda de los corridos sobre la realidad mexicana, sobre todo aquellos vinculados a las principales personalidades de la Revolución. Por otro lado, nos reveló la necesidad de entender la cultura popular como un fenómeno que no debe ser constreñido al ámbito de lo local y las prácticas subalternas.

Asimismo, la elaboración de los discos de vinilo en territorio estadounidense también impuso diversos obstáculos a la censura 
gubernamental, obligada a perseguir las grabaciones en la frontera y las importaciones de pequeños comerciantes. El temor de las autoridades no radicó solamente en la imposibilidad de actuar sobre el proceso de producción de las obras musicales, acaecido fuera de su jurisdicción legal, sino también en la existencia de una infraestructura tecnológica que permitía la recepción de las grabaciones en suelo nacional. Opciones como la rifa, el alquiler, el robo, la emigración y la compra colectiva hicieron posible que los fonógrafos llegaran incluso hasta las comunidades indígenas.

Sin embargo, algo que no pudieron censurar las autoridades gubernamentales fue la circulación oral del corrido; murmurado en las capillas como una confesión transgresora; cantado en los campamentos cristeros a la luz de las hogueras bajo el cielo de El Bajío; transmitido de padre a hijo en las familias más devotas como una irreverencia a los textos escolares. Es aquí, en este mundo de prácticas cotidianas, donde los corridos dejaron de ser noticias musicales de actualidad para convertirse en el centro de una poética de la memoria subalterna católica, capaz de sobrevivir ante la larga duración de los gobiernos "revolucionarios".70

\section{REFERENCIAS}

Acevedo y de la Llata, Concepción, El jurado de Toral y la Madre Conchita. Lo que se dijo y lo que no se dijo en el sensacional juicio, México, sin editorial ni año.

Aguilar, M. T. y A. Enríquez (coords.), Perspectiva sobre el cardenismo. Ensayos sobre economía, trabajo, política y cultura en los años 30, México, Universidad Nacional Autónoma de México, 1996.

${ }^{70}$ Con el propósito de reconstruir los usos sociales y la supervivencia de los reelaborados corridos sobre León Toral, una versión ampliada de este trabajo deberá incluir los testimonios de actores sociales octogenarios, rescatados a partir de técnicas de historia oral. 
Alonso, Ana María y Daniel Nugent, "Tradiciones selectivas en la reforma agraria y la lucha agraria: cultura popular y formación del Estado en el ejido de Namiquipa, Chihuahua", en Gilbert y Nugent, 2012, pp. 175-212.

Avitia Hernández, Antonio, Cancionero histórico chilango, México, Conaculta, 2009.

Benjamin, Thomas, La revolución mexicana. Memoria, mito e historia, México, Taurus, 2010.

BILlig, Michael, "El nacionalismo banal y la reproducción de la identidad nacional”, en Revista Mexicana de Sociología, 60: 1 (1998), pp. 37-57.

Castro, Pedro, Álvaro Obregón: fuego y cenizas de la Revolución Mexicana, México, Era, 2011.

Connell, Robert W., Masculinidades, México, Universidad Nacional Autónoma de México, 2003.

Cornejo Cancino, Tomás, "Circuitos culturales y redes sociales en Santiago de Chile (1880-1910). Un análisis microhistórico", tesis de doctorado en historia, México, El Colegio de México, 2012.

Darnton, Robert, Poesía y policía. Redes de comunicación en el París del siglo XVIII, México, Cal y Arena, 2011.

Díaz Frene, Jaddiel, "A las palabras ya no se las lleva el viento: apuntes para una historia cultural del fonógrafo en México (1876-1924)", en Historia Mexicana, LXvi:1 (261) (jul.-sep. 2016), pp. 257-298.

Dube, Saurabh, Pasados poscoloniales: colección de ensayos sobre la nueva historia y la etnografía de la India, México, El Colegio de México, 1999.

Gamio, Manuel, Mexican immigration to the United States: A Study of Human Migration and Adjustment, Chicago, Ill., University of Chicago, 1930.

Gilbert J. y D. Nugent, Aspectos cotidianos de la formación del Estado, México, Era, 2012.

Guerrero, Eduardo, Corridos históricos de la revolución desde 1910-1930 y otros notables de varias épocas, México, s.e., 1931.

GuHA, Rinajit, “La prosa de la contrainsurgencia”, en DuBE, 1999, pp. 159-208. 
Herrera Frimont, Celestino, Antología de corridos de la revolución, Pachuca, Universidad Autónoma de Hidalgo, 1980.

Hobsbawm, Eric y Terence Ranger, La invención de la tradición, Barcelona, Crítica, 2002.

Jiménez, Catalina, Así cantaban la Revolución, México, Grijalbo, 1990.

Joseph, Gilbert, "Para repensar la movilización revolucionaria en México: las temporadas de turbulencia en Yucatán, 1909 -1915”, en Gilbert y Nugent, 2012, pp. 143-174.

Joseph, Gilbert M. y Daniel Nugent, "Cultura popular y formación del estado en México”, en Gilbert y Nugent, 2002, pp. 31-52.

Knight, Alan, "Revolutionary Project, Recalcitrant people: Mexico, 19101940”, en Rodríguez O., 1990.

Knight, Alan, "Estado, revolución y cultura popular en los años treinta”, en Aguilar y Enríquez (coords.), 1996.

Knight, Alan, “Armas y arcos en el paisaje revolucionario”, en Aspectos cotidianos de la formación del Estado, México, Era, 2012, pp. 53-104.

Krauze, Enrique, Caudillos culturales de la Revolución Mexicana, México, Secretaría de Educación Pública, 1985.

LAIRD, Ross, Brunswick Records: A Discography of Recordings, 1916-1931, vol. 1, New York Sessions, 1916-1926, Westport, Connecticut, Londres, Greenwood Press, 2001.

LAIRD, Ross y Brian Rust, Discography of Okeb Records: 1918-1934, Westport, Praeger, 2004.

Leñero, Vicente, Magnicidio, el juicio a José de León Toral y a la madre Conchita por el asesinato del presidente Álvaro Obregón, Guadalajara, Ágata, 1991.

Loyola Díaz, Rafael, La crisis Obregón-Calles y el estado mexicano, México, Siglo Veintiuno Editores, 1991.

Loyola Díaz, Rafael, La crisis Obregón-Calles y el estado mexicano, MadridMéxico, Siglo Veintiuno Editores, 1998. 
Mac Gregor, Josefina, Miradas sobre la nación liberal: 1848-1948. Proyectos, debates y desafíos, México, Universidad Nacional Autónoma de México, 2010.

MalPica de LAMAdRid, Luis, La influencia del derecho internacional en el derecho mexicano. La apertura del modelo de desarrollo de México, México, Noriega Editores, 2002.

Maria y Campos, Armando de, La revolución mexicana a través de los corridos populares, México, Instituto Nacional de Estudios Históricos sobre la Revolución Mexicana, 1962.

Maria y Campos, Armando de, El teatro de género chico en la Revolución Mexicana, México, Consejo Nacional para la Cultura y las Artes, 1996.

Martín-Barbero, Jesús, De los medios a las mediaciones. Comunicación, cultura y hegemonía, Barcelona, Gustavo Gili, 2001.

Mendoza Gutiérrez, Vicente Teódulo, Corridos mexicanos, México, Fondo de Cultura Económica, 1985.

Meyer, Jean, La Cristiada: el conflicto entre la Iglesia y el Estado, México, Buenos Aires, 2005.

Meyer, Jean, La Cristiada: la guerra de los cristeros, México, Siglo Veintiuno Editores, 1997.

Moreno, Daniel A., Batallas de la revolución y sus corridos, México, Porrúa, 1978.

OchоA, Álvaro, Cancionero michoacano, 1830-1940. Canciones, cantos, coplas y corridos, Zamora, El Colegio de Michoacán, 2000.

Pérez Montfort, Ricardo, Estampas de nacionalismo popular mexicano. Ensayos sobre cultura popular y nacionalismo, México, Centro de Investigaciones y Estudios Superiores en Antropología Social, 1994.

Piccato, Pablo y Robert Buffington, True Stories of Crime in Modern Mexico, Albuquerque, University of New Mexico, 2009.

Ramírez Rancaño, Mario, El asesinato de Álvaro Obregón: la conspiración y la madre Conchita, México, Instituto Nacional de Estudios Históricos sobre las Revoluciones de México, Universidad Nacional Autónoma de México, 2014.

Requisitoria del Ministerio Público y alegatos de los defensores en el jurado de José de León Toral y Concepción Acevedo y de la Llata, reos del delito de 
bomicidio proditorio del general Álvaro Obregón, México, Talleres Gráficos de la Nación, 1928.

Río, Alfonso del, Corridos revolucionarios, México, DAPP, 1939.

Robleto, Hernán, Obregón, Toral y la Madre Conchita, México, Botas, 1935.

Rodríguez O., Jaime E., The Revolutionary Process in Mexico, Essays on Political and Social Change, Los Ángeles, The University of California Press, 1990.

Sodi de Pallares, María Elena, Los cristeros y José de León Toral, México, Cultura, 1936.

Speckman, Elisa, Del Tigre de Santa Julia, la princesa italiana y otras historias. Sistema judicial, criminalidad y justicia en la cindad de México, México, Instituto Nacional de Ciencias Penales, Universidad Nacional Autónoma de México, 2014.

Spotтswood, Richard K., Ethnic Music on Records: A Discography of Ethnic Recordings, Illinois, University of Ilinois, 1990.

Tannenbaum, Frank, “Technology and Race in Mexico", en Political Science Quarterly, 61:3 (sep. 1946), pp. 365-383.

TRIGo, Georgina, Los corridos agraristas veracruzanos, Xalapa, Universidad Veracruzana, 1989.

Vázquez Santa Ana, Higinio, Canciones, cantares y corridos mexicanos coleccionados y comentados, México, León Sánchez, 1925-1931.

VeLásquez, Rosalía, "La radiodifusión mexicana: un encuentro con su pasado”, en MAC Gregor, 2010, pp. 275-313.

Villa Rojas, Alfonso, "Los mayas del actual territorio de Quintana Roo", en Estudios etnológicos. Los mayas, México, Universidad Nacional Autónoma de México, 1995.

Walkowitz, Judith, La cindad de las pasiones terribles. Narraciones sobre peligro sexual en el Londres victoriano, Madrid, Cátedra, Universitat de València, Instituto de la Mujer, 1995. 